\title{
PENGARUH CORPORATE SOCIAL RESPONBILITY, PERSISTENSI LABA, DAN STRUKTUR MODAL TERHADAP EARNINGS RESPONSE COEFFICIENT
}

\author{
ABDUR RAHMAN DALIMUNTHE \\ Jurusan Akuntansi \\ Fakultas Ekonomi Universitas Negeri Jakarta
}

\begin{abstract}
This study aims to examine the factors that influence the Earnings Response Coefficient on state-owned companies go public listed in Indonesia Stock Exchange. These factors are the corporate social responbility, earnings persistence, and capital structure.

The study "s population is a go-public SOEs company which is listed in Indonesia Stock Exchange within 2008-2011 period. The research sample using purposive sampling. Number of companies studied were 14 (fourteen) as samples and were taken by using purposive sampling method on state-owned companies went public within 2008-2011 period in Indonesia Stock Exchange, bringing the total observations in this research were 56 observations. Methods of data analysis use multiple linear regression analysis. Hypothesis tests using the t test and F test.

These results indicate that corporate social responbility, earnings persistence, and capital structure affect the earnings response coefficient simultaneously at the state-owned company publicly traded on the Indonesia Stock Exchange listed period 2008-2011. Only the persistence of earnings are not significantly influence the earnings response coefficient. However, corporate social capital structure responbility and significant negative effect on earnings response coefficient.
\end{abstract}

Keywords: corporate social responsibility, the persistence of earnings, capital structure, earnings

respons

coefficient

\section{I.PENDAHULUAN}

Hubungan antara reaksi pasar dengan variabel akuntansi telah menjadi perhatian untuk kreditur, investor dan manajer perusahaan untuk mengetahui pergerakan harga saham (Dewi, 2003). Karena saat ini perkembangan pasar saham sangat berkembang pesat dan Jurnal IImiah Wahana Akuntansi penting dalam suatu perusahaan. Sehingga

kinerja pasar modal berpengaruh terhadap kinerja perusahaan. Pasar modal salah satu faktor pembentukan modal dan kualitas perusahaan dengan melihat harga saham perusahaan. Laporan keuangan perusahaan juga harus memberikan kondisi perusahaan yang riil untuk 
memenuhi kebutuhan stakeholder karena menggambarkan kinerja perusahaan. Laporan keuangan berguna sebagai dasar memprediksi pengambilan keputusan ekonomi terhadap laba yang diterima. Semakin tinggi laba perusahaan semakin besar pula pendapatan per lembar yang diperoleh investor. Dalam berinvestasi para investor membutuhkan informasi mengenai laporan keuangan perusahaan yang dapat mengekspentasikan suatu laba perusahaan.

Semua laporan keuangan seperti neraca, laporan arus kas, laporan laba rugi, dan catatan atas laporan keuangan perusahaan adalah bagian penting yang mengukur kinerja perusahaan. Pada kenyataannya para investor dan calon investor menilai laporan keuangan hanya terpusat pada laba perusahaan. Pernyataan tersebut terkait pada dana yang diberikan oleh investor atau calon investor guna informasi laba pada Jurnal IImiah Wahana Akuntansi laporan keuangan perusahaan dapat memberikan keputusan yang tepat. Meskipun demikian, informasi laba saja tidak saja cukup untuk menjadi acuan dalam pengambilan keputusan karena dapat terjadi bias pada informasi laba. Yang dimaksud dengan bias disini misalnya adanya praktik manajemen laba serta ketidaktepatan waktu pelaporan keuangan. Jadi bias informasi menyebabkan terjadinya kesenjangan informasi antara pihak investor dengan pihak manajemen, sehingga dapat terjadi ketidakcukupan mendapatkan informasi.

Penelitian awal mengenai hubungan antara laba akuntansi dan return dilakukan oleh Ball dan Brown (1968). Hal utama yang dijadikan parameter dari keterkaitan tersebut adalah akibat dari penilaian laba akuntansi. Teori dan bukti empiris ini menunjukkan bahwa terdapat variasi di dalam hubungan antara return sekuritas dan laba. Jika 
return sekuritas dan laba memiliki hubungan, maka laba dinyatakan sebagai kandungan informasi. Penelitian menggunakan data panel beberapa perusahaan yang beramsumsi bahwa hubungan antara laba dan return adalah homogen (Ball dan Brown, 1968). Hasil ini menyajikan hubungan positif antara expected earnings (laba kejutan) dan return tidak normal. Serta fluktuasi harga saham yang berbeda antara hari disekitar penerbitan laporan keuangan dengan hari - hari lain sebelum periode tersebut. Fluktuasi ini adalah konsep respon pasar terhadap harga saham pasar sebagai dari pengertian dari Earnings Response Coefficient (ERC). ERC adalah koefisen yang mengukur respon abnormal return sekuritas terhadap unexpected earning perusahaan yang menerbitkan sekuritas (Naimah dan Utama, 2006).

Dalam suatu pemberitahuan memiliki informasi, maka dimaksudkan pasar akan bereaksipada waktu Jurnal IImiah Wahana Akuntansi pemberitahuan tersebut diterima oleh pasar. Reaksi tersebut ditunjukkan denganperubahan harga sekuritas bersangkutan (Mulyani dkk, 2007). Penggunaan ERC adalah sebagai alternatif mengukur value relevance informasi laba. Rendahnya ERC mengungkapkan bahwalaba kurang informatif kepada investor untuk mengambil keputusan ekonomi (Murwaningsari, 2008 dalam Kusumawardhani dan Nugroho, 2010). Sehingga masih banyak informasi - informasi lainnya yang dapat digunakan sebagai pertimbangan investor dalam membuat keputusan investasi, diantaranya adalah persistensi laba dan struktur modal yang juga sebagaifaktor yang mempengaruhi respon pasar berbeda beda terhadap laba (Scott, 2000 dalam Kusumawardhani dan Nugroho, 2010). Persistensi laba adalah ciri laba yang menyatakan kemampuan perusahaan 
untuk mempertahankan jumlah laba yang diperoleh sekarang dan masa yang akan datang. Nilai saat ini dari revisi atas laba masa yang akan datang merupakan ekspentansi yang diperoleh pemegang saham (Kormendi dan Lipe, 1997 dalam Palupi, 2006). Perusahaan yang memilili tingkat hutang tinggi akan mempengaruhi laba meningkat pada kreditor dibanding pemegang saham. Dilain sisi, terdapat resiko kebangkrutan dalam jangka panjang. Hal ini membuat ERC akan dipengaruhi struktur modal perusahaan (Willjayanti, 2012).

Pandangan informasi untuk
pelaporan keuangan adalah suatu
pendekatan yang mengakui
pertanggungjawaban individu dalam
mempekirakan kinerja perusahaan di
masa yang akan datang dan bahwa
menitik beratkan pada penyediaan
informasi yang berguna untuk tujuan ini.
Pendekatan tersebut mengakui bahwa pasar
Jurnal Ilmiah Wahana Akuntansi

akan bereaksi dengan adanya informasi dari berbagai sumber termasuk laporan keuangan (Rahmawati, 2012: 59-60). Dan ERC berimplikasi untuk meningkatkan pemahaman respon pasar menggambarkan cara yang dapat meningkatkan keputusan yang bermanfaat tentang laporan keuangan. Hasil penelitian empiris dalam area ini mendukung teori efesiensi pasar dan berhubungan dengan teori keputusan (Rahmawati, 2012: 62).

Informasi dikatakan informatif apabila dapat mengubah kepercayaan para investor dalam pengambilan keputusan investasi. Adanya informasi baru diluar laporan keuangan akan meningkatkan kepercayaan dikalangan investor terhadap suatu perusahaan. Sekarang informasi banyak mendapat sorotan yang mengenai pertanggungjawaban sosial perusahaan. Kesadaran akan pentinganya mempraktikkan Corporate Social Responbility (CSR) menjadi trend dunia 
sejalan dengan semakin banyaknya kepedulian masyarakat global terhadap produk produk yang ramah lingkungan dan diproduksi dengan memperhatikan aturan sosial dan prinsip hak asasi manusia (HAM) (Susilawati, 2010).

Mengenai asosiasi antara informasi CSR (termasuk lingkungan dan juga human capital), yang pada umumnya bersifat sukarela, diungkapkan pada laporan tahunannya dengan kinerja pasar. Dalam perbedaan reaksi pasar terhadap pengumuman laba yang didasari premis bahwa informativeness of earnings akan semakin besar ketika terdapat ketidakpastian mengenai prospek perusahaan dimasa yang akan datang, maka earnings response coefficient semakin tinggi. Dan apabila perusahaan melakukan pengungkapan informasi CSR dapat mengurangi ketidakpastian prospek perusahaan. Maka, dengan pengungkapan informasi CSR akan menurunkan ERC. Bahwa investor mengapresiasikan informasi CSR Jurnal IImiah Wahana Akuntansi yang diungkapkan perusahaan sebagai salah satu dasar pengambilan keputusan investasinya (Sayekti dan Wondabio, 2007).

Penelitian ini menyajikan kembali beberapa faktor faktor yang sudah ada tentang hubungan dengan ERC dalam penelitian sebelumnya. Banyak variabel yang diuji mendapatkan hasil yang tidak signifikan atau negatif, dengan berpendapat bahwa penelitian kemungkinan besar akan mendapatkan hasil yang berbeda dalam konteks waktu penelitian dan objek atau sampel yang diteliti, maka peneliti menggunakan variabel yang sudah digunakan pada penelitian sebelumnya. Besaran perusahaan merupakan proksi dari the informativeness of price. Perusahaan yang besar dianggap memiliki informasi yang lebih banyak dibandingkan perusahaan kecil. Konsekuensinya semakin informatif kurang maka harga saham maka semakin kecil pula muatan informasi earnings saat ini. 
Kontribusi yang diharapkan dapat diberikan dari penelitian ini adalah bahwa hasil pengujian empiris ini dapat memberikan masukan bagi badan penyusun standar akuntansi dan badan otoritas pasar modal mengenai relevansi dari pengungkapan informasi CSR dalam laporan tahunan perusahaan. Hal ini selanjutnya dapat menjadi masukan dalam mempertimbangkan apakah informasi CSR sudah waktunya diungkapkan dalam laporan tahunan perusahaan atau tidak.

Mengamati hal ini, maka peneliti mencoba menganalisis variabel yang berpengaruh terhadap Earnings Response Coefficient (ERC). Variabel yang digunakan dalam peneltian ini terhadap ERC adalah Corporate Social Responbility, Persistensi Laba, dan Struktur Modal.

Berdasarkan latar belakang yang telah diuraikan, maka peneliti tertarik untuk melakukan penelitian dengan judul: 'PENGARUH CORPORATE SOCIAL Jurnal IImiah Wahana Akuntansi
RESPONBILITY, PERSISTENSI

LABA, DAN STRUKTUR MODAL TERHADAP EARNINGS RESPONSE COEFFICIENT'.

\section{KAJIAN TEORITIK \\ Deskripsi Konseptual}

\section{Earnings Response Coefficient (ERC)}

ERC merupakan pengaruh laba abnormal (unexpected earnings) terhadap Cumulative Abnormal Return (CAR), yang ditunjukkan melalui slope coeficient dalam regresi abnormal return saham dengan unexpected earnings (Scott, 2007). Hal ini menunjukkan bahwa ERC adalah reaksi CAR terhadap laba yang diumumkan oleh perusahaan.

Ada beberapa hal yang menyebabkan respon pasar yang berbedabeda terhadap laba yaitu persistensi laba, beta, struktur permodalan perusahaan, kualitas laba, growth opportunities, dan ukuran perusahaan (Scott, 2003). Nilai earnings response coefficients diprediksi 
lebih tinggi jika laba perusahaan lebih persisitensi di masa depan. Demikian juga jika kualitas laba semakin baik, maka diprediksi nilai ERC akan semakin tinggi. Beta mencerminkan risiko sistematis. Investor akan menilai laba sekarang untuk memprediksi laba dan return dimasa yang akan datang. Jika future return tersebut semakin berisiko, maka reaksi investor terhadap unexpected earnings perusahaan juga semakin rendah (Scott, 2003).

Laba memiliki kandungan informasi yang tercermin dalam harga saham (Easton dan Harris, 1991 dalam Hidayati dan Murni, 2009). Penelitian ini membuktikan bahwa laba memiliki nilai relevan yang diketahui dari pengaruhnya terhadap reaksi pasar yang digambarkan dalam harga saham. Perubahan harga saham bergerak sesuai dengan kepercayaan investor, sejalan dengan Eficiency Market Theory yang menyatakan bahwa pasar akan bereaksi cepat terhadap informasi yang baru, sehingga sesaat sebelum dan Jurnal IImiah Wahana Akuntansi sesudah laporan keuangan dikeluarkan, informasi mengenai angka laba yang dipublikasikan akan memengaruhi tingkah laku investor. Peningkatan laba abnormal (unexpected earnings) diikuti oleh return abnormal positif dan penurunan laba abnormal diikuti oleh tingkat return abnormal negatif (Ball dan Brown, 1968). Hasil ini menunjukkan bahwa adanya hubungan yang signifikan antara pengumuman laba perusahaan dengan perubahan harga saham. Seberapa jauh respon pasar terhadap informasi laba dikenal dengan penelitian ERC.

\section{Corporate Social Responbility}

"Corporate social responsibility is a commitment to improve community well-being through discretionary business practices and contributions of corporate resources". The World Business Council for Sustainable Development (WBCSD, 2006), menggambarkan bahwa "Corporate social responsibility as "business" commitment to contribute to 
suistanable economic development, working with employees, their families, the local community, and society at large to improve their quality of life" (Kotler dan Lee,2005 dalam Asmiranti, 2011).

Pertanggungjawaban sosial perusahaan (Corporate Social Responbility (CSR)) adalah mekanisme bagi suatu organisasi untuk secara sukarela mengintegrasikan perhatian terhadap lingkungan dan sosial ke dalam operasinya dan interaksinya dengan stakeholders, yang melebihi tanggung jawab organisasi di bidang hukum. Dengan konsep ini, kendati secara moral tujuan perusahaan untuk mengejar keuntungan adalah sesuatu yang baik, tetapi tidak dengan sendirinya perusahaan dibenarkan untuk mencapai keuntungan itu dengan mengorbankan kepentingan pihak-pihak lain (Darwin, 2004).

Pemikiran yang melandasi corporate social responsibility yang sering dianggap inti dari etika bisnis adalah bahwa Jurnal IImiah Wahana Akuntansi perusahaan tidak hanya mempunyai kewajiban ekonomi dan legal (artinya kepada pemegang saham atau shareholder) tetapi juga kewajibankewajiban terhadap pihak-pihak lain yang berkepentingan (stakeholder) yang jangkauannya melebihi kewajiban kewajiban diatas. Tanggung jawab sosial dari perusahaan terjadi antara sebuah perusahaan dengan semua stakeholder, termasuk di dalamnya adalah pelanggan atau customer, pegawai, komunitas, pemilik atau investor, pemerintah, supplier bahkan juga kompetitor (Nurlela dan Islahudin, 2008).

\section{Persistensi Laba}

Persistensi laba merupakan salah satu komponen nilai prediksi laba dalam menentukan kualitas laba, dan persistensi laba tersebut ditentukan oleh komponen akrual dan aliran kas dari laba sekarang, yang mewakili sifat transitori dan permanen laba (Sloan dalam Wijayanti, 2006). Persistensi laba adalah revisi dalam laba 
yang diharapkan di masa depan (expected future earnings) yang diimplikasi oleh laba tahun berjalan (current earnings) (Penman dalam Wijayanti, 2006).

Besarnya revisi ini menunjukkan tingkat persistensi laba. Inovasi terhadap laba sekarang adalah informatif terhadap laba masa depan, yaitu manfaat masa depan yang diperoleh pemegang saham. Harga saham merupakan nilai sekarang manfaat masa depan yang diperoleh pemegang saham. Nilai sekarang dari revisi atas laba masa depan dapat memperkirakan nilai sekarang revisi manfaat masa depan ekspektasiannya, yaitu dalam harga saham (Kormendi dan Lipe dalam Palupi, 2006).

Semakin kecil nilai revisi laba masa depan (semakin kecil persistensi laba akuntansi), semakin kuat hubungan laba dengan abnormal return (semakin besar koefisien respon laba). Selain itu, persistensi laba ditentukan oleh Jurnal IImiah Wahana Akuntansi komponen akrual dan aliran kas yang terkandung dalam laba saat ini (Penman dalam Wijayanti, 2006).

\section{Struktur Modal}

Modal menjadi salah satu aspek penting dalam perusahaan karena baik dalam pembukaan bisnis maupun pengembangannya, modal sangatlah diperlukan. Oleh sebab itu perusahaan harus menentukan seberapa banyak modal yang diperlukan untuk membiayai bisnisnya. Sumber dana bagi perusahaan dapat diperoleh dari dalam maupun dari luar perusahaan. Dana dari dalam perusahaan, yaitu melalui laba ditahan dan depresiasi, sedangkan dana dari luar perusahaan berasal dari para kreditur dan dana dari peserta yang mengambil bagian dari perusahaan yang akan menjadi modal sendiri (Ardilla, 2012).

Keputusan pendanaan atau keputusan atas struktur modal merupakan suatu keputusan keuangan yang berkaitan 
dengan komposisi utang, saham preferen dan saham biasa yang harus digunakan oleh perusahaan. Keputusan struktur modal secara langsung berpengaruh terhadap besarnya resiko yang ditanggung oleh pemegang saham beserta besarnya tingkat pengembalian atau tingkat keuntungan yang diharapkan (Brigham dan Houston, 2001). Keputusan struktur modal tidak saja berpengaruh terhadap profitabilitas perusahaan, tetapi juga berpengaruh terhadap risiko keuangan yang dihadapi perusahaan. Risiko keuangan tersebut meliputi kemungkinan ketidakmampuan perusahaan untuk membayar kewajibannya dan kemungkinan tidak tercapainya tingkat laba yang ditargetkan perusahaan (Ardilla, 2012)

Struktur modal diukur dengan leverage perusahaan yang menyebabkan investor menjadi kurang percaya terhadap laba yang dipublikasikan oleh suatu perusahaan, yang pada akhirnya akan Jurnal IImiah Wahana Akuntansi mengakibatkan respon pasar menjadi relatif rendah. Respon pasar yang relatif rendah ini pada akhirnya akan mencerminkan bahwa laba suatu perusahaan kurang atau tidak berkualitas (Jang, dkk, 2007).

\section{Kerangka Teoritik}

Kerangka pemikiran earnings response coefficient dalam penelitian ini dipengaruhi oleh beberapa faktor yaitu corporate social responbility, persistensi laba, dan struktur modal. Berdasarkan Signaling Theory bahwa pasar akan merespon setiap informasi yang diberikan, semakin baik kualitas suatu informasi maka semakin baik pula respon yang diberikan oleh pasar, dan atas dasar asumsi teori kegenan yaitu keterkaitan antara pemilik dan agen atau keterkaitan keagenan (Jensen dan Meckling, 1976), bahwa manajemen mencapai kepentingan sekaligus mewujudkan tujuan pemilik yakni meningkatkan laba. 


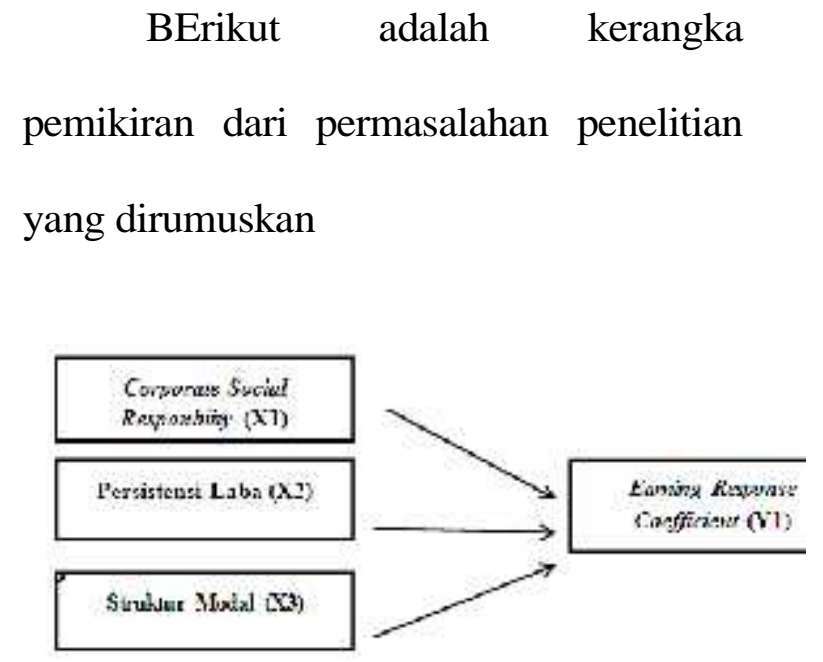

Sumber data: diolah dari data penelitian

Berdasarkan kerangka pemikiran dan asumsi di atas, maka dibuat hipotesis sebagai berikut :

$\mathrm{H}_{1}$ : Pengaruh Corporate Social Responbilty terhadap Earnings Response Coefficient

$\mathrm{H}_{2}$ : Pengaruh Persitensi Laba terhadap Earnings Response Coefficient

H3 : Pengaruh Struktur Modal terhadap

Earnings Response Coefficient

\section{OBJEK DAN METODOLOGI PENELITIAN}

\section{Tujuan Penelitian}

Berdasarkan rumusan masalah yang telah diuraikan di sebelumnya, maka penelitian ini dilakukan bertujuan untuk:

1. Mengetahui apakah terdapat Jurnal IImiah Wahana Akuntansi pengaruh antara corporate social responbility terhadap earnings response coefficient.

2. Mengetahui apakah terdapat pengaruh antara persistensi laba terhadap earnings response coefficient.

3. Mengetahui apakah terdapat pengaruh antara struktur modal terhadap earnings response coefficient.

4. Mengetahui apakah terdapat pengaruh antara corporate social respinbility, persistensi laba, dan strukur modal terhadap earnings response coefficient.

\section{Objek dan Ruang Lingkup Penelitian}

Objek dari penelitian yang berjudul "Pengaruh Corporate Social Responbility, Persistensi Laba, dan Struktur Modal Terhadap Earnings Response Coefficient" adalah perusahaan manufaktur sektor BUMN go public yang 
terdaftar di Bursa Efek Indonesia (BEI) selama tahun 2008, 2009, 2010 dan 2011.

\section{Metode Penelitian}

Penelitian ini menggunakan jenis penelitian kuantitatif yaitu penelitian yang menggunakan angka, mulai dari pengumpulan data, penafsiran terhadap data, serta penampilan dari hasilnya yang bertujuan untuk menemukan ada tidaknya hubungan antara variabel.

\section{Jenis dan Sumber Data}

Populasi adalah keseluruhan dari objek yang diteliti dari suatu penelitian. Populasi dari penelitian ini adalah perusahaan BUMN yang terdaftar di Bursa Efek Indonesia dari tahun 2008 sampai dengan 2011. Sedangkan sampel adalah sebagian dari populasi yang dianggap dapat mewakili populasi untuk diteliti. Dalam hal ini, sampel penelitian adalah yang memenuhi kriteria tertentu dikehendaki peneliti dan kemudian dipilih berdasarkan pertimbangan tertentu sesuai dengan tujuan penelitian.
Sampel yang dipilih dengan kriteria sebagai berikut :

a. Perusahaan yang terdaftar di BEI tahun 2008 sampai dengan 2011 dengan pertimbangan ketersediaan data.

b. Perusahaan dari sektor BUMN go public.

c. Perusahaan yang memiliki data laporan keuangan yang tersedia.

\section{Operasionalisasi Variabel Penelitian}

Untuk teknik pengumpulan data yang digunakan dalam penelitian ini adalah secara metode purposive sampling. Dan variabel yang digunakan penelitian ini terdiri atas variabel dependen dan independen. Variabel dependen dari penelitian ini sendiri adalah earnings response coefficient. Dan variabel independennya adalah corporate social responbility, persistensi laba, dan struktur modal.

Terdapat empat variabel pada penelitian ini yang terbagi menjadi tiga variabel bebas dan satu variabel terikat.

\section{Teknik Analisis Data}

Jurnal IImiah Wahana Akuntansi 
Teknik analisis data yang digunakan untuk menguji hipotesis adalah regresi linier berganda yaitu untuk menguji dan menganalisis, baik secara parsial maupun simultan pengaruh corporate social responbility, persistensi laba, dan struktur modal terhadap earnings response coefficient pada perusahaan - perusahaan yang terdaftar di Bursa Efek Indonesia periode 2008- 2011. Data diolah dengan program Statistical Package For Social Science (SPSS)

\section{PEMBAHASAN}

Dari hasil analisa dengan menggunakan analisis regresi linier berganda dan pengujian hipotesis dapat dijelaskan faktor-faktor yang mempengaruhi earning response coefficient Sebelum dilakukan analisis, terlebih dahulu dilakukan pengujian asumsi klasik. Hasil dari pengujian asumsi klasik menunjukkan bahwa variabel pengaruh corporate social responbility, persistensi laba dan struktur modal menunjukkan memenuhi asumsi klasik dan berdistribusi normal.

\section{Pengaruh Corporate Social}

\section{Responbiity terhadap Earnings Response Coefficient}

Hasil pengujian pengaruh variabel terhadap CSR dengan menggunakan uji t, diperoleh nilai corporate social responsibility ttable 1,69389 < thitung 2,894 dan tingkat signifikan pada level 0,007 (kurang dari 5\%), maka keputusannya adalah menolak H0 dan H1 diterima. Hasil pengujian hipotesis menunjukkan hipotesis diterima. Hasil penelitian ini menunjukkan bahwa CSR berpengaruh signifikan terhadap ERC.

Dan berdasarkan data penelitian ini dapat dilihat pada PT Adhi Wijaya masing masing mempunyai nilai CSR 0,4304 untuk periode 2008 dan 0,4937 untuk periode 2009 ini berarti mengalami kenaikkan sebesar 0,0633 akan tetapi nilai ERC PT Adhi Wijaya periode 2008 senilai 0,1281 dan periode 2009 senilai $-0,4355$ berarti mengalami penurunan sebesar 0,5636. Maka, nilai CSR perusahaan berdampak negatif terhadap ERC perusahaan. 
Investor beranggapan bahwa perusahaan yang melaksanakan pengungkapan CSR maka perusahaan akan menambah biaya atau alokasi dana untuk CSR sehingga profit perusahaan akan berkurang, hal tersebut akan berdampak pada return yang akan diterima oleh investor, maka investor tetap menggunakan informasi laba sebagai harapan laba dimasa mendatang. Sehingga semakin tinggi pengungkapan CSR perusahaan maka semakin rendah respon investor dan ERC juga akan semakin rendah. Hasil ini juga memberikan dukungan terhadap penelitian yang sebelumnya telah dilakukan oleh Sayekti dan Wondabio (2007).

\section{Dalam penelitian Widiastuti} (2006) apabila perusahaan melakukan pengungkapan informasi CSR dalam laporan tahunan akan dapat mengurangi dari informativess of earnings yang semakin besar karena prospek perusahaan dimasa depan tidak pasti. Dengan Jurnal IImiah Wahana Akuntansi demikian pengungkapan CSR tersebut juga dapat menurunkan ERC. Hal ini mengindikasikan bahwa investor mengapresiasikan informasi CSR perusahaan sebagai salah satu dasar pengambilan keputusan investasinya.

\section{Pengaruh Persistensi Laba terhadap Earnings Response Coefficient}

Hasil pengujian persistensi laba diperoleh thitung $1,284<$ ttabel 1,69389 dan tingkat signifikan pada level 0,208 (lebih dari 5\%), maka keputusannya adalah menerima $\mathrm{H} 0$ dan $\mathrm{H} 1$ ditolak. Berarti persistensi laba tidak berpengaruh terhadap earnings response coefficient. Makin besar variansi laba sekarang dan laba masa depan, makin kecil persistensi laba, dan makin besar koefisien respon laba.

Dari data penelitian ini dapat dilihat pada PT Kimia Farma Tbk untuk tahun 2009 dan 2010 mengalami kenaikkan nilai persistensi laba sebesar 
0,067 dan 1,0908. Peningkatan nilai persistensi laba ini tidak konsisten terhadap nilai ERC PT Kimia Farma Tbk yang mengalami penurunan sebesar 1,9994 untuk tahun 2009 dan mengalami peningkatan sebesar 0,2967 pada tahun 2010. Maka, nilai persistensi laba tidak berpengaruh terhadap earning response coefficient.

Hasil penelitian ini sesuai dengan Ali dan Zahrowi (2002) dalam Imroatussolihah (2013) yang menyatakan bahwa persistensi laba tidak berpengaruh terhadap earnings response coefficient, adanya komponen komponen transitory dalam laba menyebabkan laba kurang dapat dijadikan pengukur earnings response coefficient. Banyaknya komponen transitory hanya akan berpengaruh terhadap laba saat ini akan tetapi tidak berpengaruh terhadap laba di masa yang akan datang. Komponen transitory sifatnya tidak berulang, artinya aktifitas yang tidak Jurnal IImiah Wahana Akuntansi biasa dilakukan dan tidak selalu terulang di masa depan. Komponen transitory ini menyebabkan kurang relevannya laba digunakan untuk memprediksi kebijakan di masa datang.

Dan penelitian yang dilakukan Hapsari (2010) dalam Imroatussolihah (2013) menjelaskan bahwa investor tidak merespon terhadap perubahan laba meskipun perusahaan telah menunjukkan persistensi laba yang negatif untuk dimasa yang akan datang. Hal ini menunjukkan bahwa dalam menentukan investasinya investor tidak hanya menilai berdasarkan informasi laba, akan tetapi investor juga menilai informasi lain yang mungkin berpengaruh terhadap investasinya.

Jadi, persistensi laba tidak selalu dapat dijadikan patokan dalam penentuan kebijakan investasi di masa depan karena dalam laba terdapat kemungkin komponen transitory yang tidak terjadi berulang sehingga tidak dapat 
mengindentifikasikan laba di masa yang akan datang.

\section{terhadap Earnings Response Coefficient}

3. Pengaruh Struktur Modal

Hasil pengujian pengaruh variabel struktur modal terhadap terhadap ERC dengan menggunakan uji t, diperoleh nilai ttabel $1,69389<$ thitung 2,905 dan tingkat signifikan pada level 0,007 (kurang dari 5\%), maka keputusannya adalah menolak H0 dan $\mathrm{H} 1$ diterima. Maka dari hasil tersebut struktur modal berpengaruh terhadap earning response coefficient. Dan hal ini menjelaskan bahwa perusahaan yang menggunakan struktur modal dengan tujuan agar keuntungan yang diperoleh lebih besar dari pada biaya asset dan sumber dananya, dengan demikian akan meningkatkan keuntungan pemegang saham. Sebaliknya strukur modal juga meningkatkan variabilitas atau resiko keuntungan, karena jika perusahaan ternyata mendapatkan keuntungan yang lebih rendah dari biaya tetapnya maka Jurnal IImiah Wahana Akuntansi penggunaan strukur modal akan menurunkan keuntungan pemegang saham.

Berdasarkan data penelitian ini, dapat dilihat dari nilai struktur modal pada PT Bank Rakyat Indonesia mempunyai nilai struktur modal 0,9091 untuk tahun 2008 dan 0,9140 untuk tahun 2009, berarti mengalami kenaikkan sebesar 0,0049. Akan tetapi untuk nilai ERC PT Bank Rakyat Indonesia mengalami penurunan sebesar 2,2187. Maka, struktur modal berpengaruh negative terhadap earning response coefficient.

Hasil penelitian ini konsisten dengan Mulyani (2007) yang menunjukkan bahwa earnings response coefficient berpengaruh negatif dengan tingkat leverage. Perusahaan yang mempunyai tingkat leverage tinggi berarti memiliki hutang yang lebih besar dibandingkan modal. Dengan demikian apabila terjadi peningkatan laba maka yang diuntungkan adalah pihak debtholders, karena debitor 
mempunyai keyakinan bahwa perusahaan akan mampu melakukan pembayaran atas hutang. Namun hal ini akan direspon negatif oleh investor karena investor beranggapan bahwa perusahaan akan lebih mengutamakan pembayaran hutang daripada dividen .

\section{KESIMPULAN DAN SARAN}

\section{Kesimpulan}

Penelitian ini bertujuan untuk mengetahui pengaruh corporate social responbility, persistensi laba dan struktur modal terhadap earnings response coefficient. Berdasarkan hasil penelitian maka diperoleh kesimpulan sebagai berikut:

1. Corporate social responbilty memiliki pengaruh negatif pada earnings response coefficient, hal ini menunjukkan bahwa secara umum pihak perusahaan mengapresiasikan tanggung jawab terhadap lingkungan sekitar merupakan tindakan positif akan tetapi dilihat dari sisi pihak investor hal ini berdampak pengeluaran biaya meningkat untuk tanggung jawab lingkungan dan dapat mengurangi laba perusahaan.
2. Persistensi laba tidak memiliki pengaruh pada earnings response coefficient, adanya komponen transitory yang merupakan penyebab kurang relevannya laba digunakan untuk memprediksi kebijakan dimasa datang. Hal ini tidak hanya informasi laba perusahaan dijadikan tolak ukur bagi investor untuk melakukan investasi akan tetapi penilaian informasi lain yang dapat juga berpengaruh menentukkan kebijakan investasinya.

3. Struktur modal memiliki pengaruh negatif pada earnings response coefiicient, hal ini dikarenakan setiap informasi modal yang dimiliki perusahaan dapat direspon negatif karena para investor beranggapan perusahaan akan lebih mengutamakan pembayaran hutang daripada dividen.

\section{Implikasi}

Didalam penelitian ini ada beberapa implikasi yaitu diantaranya:

1. Pengaruh corporate social responbility atau pengungkapan tanggung jawab sosial terhadap besaran respon laba perusahaan Jurnal IImiah Wahana Akuntansi 
mengakibatkan menurun. Karena investor beranggapan bahwa perusahaan yang melaksanakan pengungkapan tanggung jawab sosial maka perusahaan akan menambah biaya atau alokasi dana untuk tanggung jawab sosial sehingga profit perusahaan akan berkurang, hal tersebut akan berdampak pada return yang akan diterima oleh investor.

2. Persistensi laba mencerminkan kualitas laba perusahaan yang menunjukkan bahwa perusahaan mampu mempertahankan laba dari waktu ke waktu. Semakin besar persistensi laba suatu perusahaan maka semakin besar pula laba yang dapat diharapkan oleh investor di masa datang. Tetapi hal ini tidak menjadi tolak ukur apabila perusahaan tidak dapat mempertahankan labanya dengan baik dari waktu ke waktu, maka investor tidak merespon terhadap perubahan laba meskipun perusahaan telah menunjukkan persistensi laba yang positif untuk Jurnal IImiah Wahana Akuntansi masa datang. Hal ini menunjukkan bahwa dalam menentukan investasinya investor tidak hanya menilai berdasarkan informasi laba, akan tetapi investor juga menilai informasi lain yang mungkin berpengaruh terhadap investasinya.

3. Perusahaan dengan prospek yang menguntungkan akan menghindari penggunaan hutang yang melebihi target struktur modal yang normal. Prospek perusahaan tidak hanya dilihat investor dari kemampuan perusahaan dalam memperoleh laba, tetapi juga penggunaan hutang oleh perusahaan karena hal tersebut akan berpengaruh terhadap tingkat keuntungan yang diperoleh perusahaan dan berdampak pada return yang akan diterima oleh investor.

\section{Saran}

Berdasarkan hasil penelitian, peneliti memiliki beberapa saran yang perlu disampaikan:

1. Sebaiknya, penelitian selanjutnya dapat menggunakan sampel perusahaan yang jumlahnya lebih banyak, misalnya menggunakan perusahaan LQ 45 yang terdaftar di Bursa Efek Indonesia. Dan juga 
peneliti selanjutnya sebaiknya menggunakan periode lebih dari tiga tahun, sehingga sampel yang diperoleh semakin banyak.

3. Untuk variabel yang mempengaruhi earnings response coefficient tidak hanya corporate social responbility, persistensi laba, atau struktur modal saja akan tetapi dapat memasukkan variabel-variabel lainnya seperti kualitas laba, profitabilitas, size, beta, dan growth opportunie.

4. Dan untuk pengukuran corporate social responbility juga dapat dilihat standar GRI terbaru yang setiap periode berubah. 


\section{DAFTAR PUSTAKA}

Anggraini, Fr. Reni Retno. 2006.

Pengungkapan Informasi

Sosial dan Faktor- Faktor yang

Mempengaruhi Pengungkapan

Informasi Sosial dalam Laporan

Keuangan Tahunan.(Studi Empiris

pada Perusahaan-Perusahaan yang

terdaftar di Bursa Efek

Jakarta).Simposium Nasional

Akuntansi 9.

Ardilla, Isna. 2012. “Analisis Faktor-

Faktor Yang Mempengaruhi

Earnings Response Coefficient

Studi Empiris Pada Perusahaan

Yang Terdaftar Di Jakarta Islamic

Index", Tesis. Program Pasca

Sarjana Univesitas Sumatera Utara,

Medan.

Ball, Ray and Philip Brown. 1968. An

Empirical Evaluation of Accounting

Numbers. Journal Accounting

Research (Autumn 1968): 159-177.

Jurnal IImiah Wahana Akuntansi
Belkaoui, Ahmed Riahi. 2006. Teori Akuntansi. Buku 1. Edisi 5. Salemba Empat. Jakarta.

Brigham, Eugene F. and Joel F. Houston. 2001. Manajemen Keuangan. Edisi kedelapan. Alih Bahasa Dodo Suharto dan Herman Wibowo. Jakarta: Erlangga.

Collins, D.W dan S.P Khotari, 1989. “An Analisys of The Intertemporal and CrossSectional Determinants of Earnings Response Coefficient", Journal of Accounting and Economic. Vol. 11, pp. 143-182

Darwin, Ali. 2004. Penerapan Sustainability Reporting Di Indonesia. Konvensi Nasional Akuntansi V, Program Profesi Lanjutan. Yogyakarta, $13-15$ Desember

Dewi, A.A.A. Ratna. 2003. Pengaruh Konservatisma Laporan Keuangan Terhadap Earnings

Response Coefficient. Simposium 
Nasional Akuntansi VI Surabaya, 16

-17 Oktober.

Easton, P.D dan E.M. Zmijewski, 1989. "Cross-Sectional Variation in The

Stock Market Response to

Accounting

Earnings

Announcements", Journal of

Accounting and Economic. Vol. 11, pp. 117-141.

Ghosh, Arvin, Francis Cai, dan Wenhui

Li, 2000. "The Determinants of

Capital Structure" American Business

Review. Vol. 18, No 2, pp. 129

Ghozali, Imam. 2005. Aplikasi Analisis Multivariate Dengan Program SPSS. Semarang: Badan Penerbit Universitas Diponegoro.

Hasibuan, Muhammad Rizal. 2001. "Pengaruh Karakteristik Perusahaan terhadap Pengungkapan Sosial Dalam Laporan Tahunan Emiten di BEJ dan
BES”, Tesis Program Magister Undip, Semarang.

Hidayati, Naila Nuur dan Sri Murni, 2009. "Pengaruh Pengungkapan

Corporate Social Responsibility Terhadap Earnings Response

Coefficient pada Perusahaan High Profile", Jurnal Bisnis dan Akuntansi. Vol. 11, No. 1, April, hal.1-18.

Imroatussolihah, Ely. 2013. Pengaruh Risiko, Leverage, Peluang Pertumbuhan, Persistensi Laba Dan Kualitas Tanggung Jawab Sosial Perusahaan Terhadap Earning Response Coefficient Pada Perusahaan High Profile. Jurnal Ilmiah Manajemen. Vol. 1 No.1. Januari

Jang, Lesia., Bambang Sugiarto, dan Dergibson Siagian. 2007. Faktor-faktor yang Mempengaruhi Kualitas Laba Pada Perusahaan 
Manufaktur di BEJ. Akuntabilitas, Vol. 6, No. 2 : hal. 142-149.

Jansen, M.C dan W.H. Mecklin, 1976. "Theory of the Firm : Managerial agency costs and ownership structure", Journal of Financial Economics. Vol.3, No.4, pp. 305360.

Kesuma, A. 2009. Analisis FaktorFaktor yang Mempengaruhi Struktur Modal Serta Pengaruhnya terhadap Harga Saham Perusahaan Real Estate yang Go Public di Bursa Efek Indonesia. Jurnal Manajemen dan Kewirausahaan, 11 (1), 38-45.

Kormendi, Roger dan Robert Lipe, 1987. "Earnings Innovation, Earnings Persistence, and Stock return", Journal of Business. Vol. 60, No 3, pp. 323-345.

Kusumawardhani, Indra dan Joko Setiyo Nugroho. 2010. Pengaruh
Corporate Social Responbility, Size, Dan Profitabilitas Terhadap Earnings Response Coefficient. Kajian Akuntansi. Vol. 5. No. 1. Juni Mayangsari. 2004. "Bukti Empiris Pengaruh Spesialisasi Industri Auditor Terhadap Earnings Response Coefficient". Jurnal Riset Akuntansi Indonesia. Vol. 7. No. 2. Mei. Hal: $154-178$

Mulyani, S., Asyik, N. F., dan Andayani. (2007). Faktor-Faktor yang Mempengaruhi Earnings Response Coefficient pada Perusahaan yang Terdaftar di Bursa Efek Indonesia. JAAI, 11 (1), 35-45.

Myers, Stewart C, 1984. "The Capital Structure Puzzle", Journal of Finance . Vol. 33, July: Hal. 573-592

Modigliani, F. and M. H. Miller. 1963. "Corporate Income Tax and the cost of Capital: A Correction”, American Jurnal IImiah Wahana Akuntansi 
Economic Review . Vol. 53, No 3, hal.433 443

Nurlela, dan Islahudin. 2008. Pengaruh

Corporate Social Responsibility Terhadap Nilai Perusahaan dengan Prosentase Kepemilikan Manajemen sebagai Variabel Moderating. Simposium Nasional Akuntansi XI.

Naimah, Z., dan Utama, S. (2006). Pengaruh Ukuran Perusahaan Pertumbuhan dan Profitabilitas Perusahaan Terhadap Koefisien Respon Laba dan Koefisien Respon

Nilai Buku Ekuitas: Studi pada Perusahaan Manufaktur di Bursa Efek Jakarta. Simposium Nasional Akuntansi 9 Padang (AKPM 12).

Palupi, Margaretta Jati. 2006. Analisis Faktor - Faktor Yang Mempegaruhi Koefisien Respon Laba: Bukti Empiris Pada Bursa Efek Jakarta. Jurnal Ekubank. Vol. 3. November.

Rahmawati. Teori Akuntansi Keuangan. Yogyakarta: Graha Ilmu, 2012.

Saidi, 2001. "Faktor-faktor Yang Mempengaruhi Struktur Modal pada Jurnal IImiah Wahana Akuntansi
Perusahaan Manufaktur

Go Public di BEJ", Jurnal Bisnis dan

Ekonomi. Vol. 11, No. 1 Edisi Maret, Hal. 44-58

Sayekti, Yosefa dan Ludovicus Sensi Wondabio. 2007. Pengaruh CSR

Disclosure terhadap Earnings Response Coefficient. "Suatu Studi Empiris Pada Perusahaan yang Terdaftar Di Bursa Efek Jakarta”, Simposium Nasional Akuntansi X Makassar. Juli.

Scott, William R. 2000, Financial Accounting Theory, $2^{\text {nd }}$ edition, Prentice-Hall Canada Inc., Scarborough, Ontario.

Sloan, R.G, 1996. "Do Stock Prices Fully Reflect Information in Accruals and Cash Flow About Future Earnings?", The Accounting Review .Vol. 71, No. 3, pp 289-315.

Spicer, Barry H. (1978), “Investors, Corporate Social Performance and Information Disclosure: An Empirical Study", The Accounting 
Review, Vol. 53, No. 1, Jan, pp. 94111

Suwardjono, 2005. Teori Akuntansi Perekayasa Pelaporan Keuangan. Yogyakarta. BPFE.

Suaryana, Agung. 2005. "Pengaruh Konservatisme Laba Terhadap Koefisien Respon Laba”. hal. 2

Susilawati, Christine Dwikarya, 2008.

“Faktor-faktor Penentu ERC”, Jurnal Ilmiah Akuntansi. Vol. 7, No.2, hal. 146-161.

Syafrudin, 2004. "Pengaruh Ketidaktepatanwaktuan Penyampaian Laporan Keuangan pada Earnings Response Coefficient : Studi di Bursa Efek Jakarta",Simposium Nasional Akuntansi VII. Hal. 754-776.

Wijayanti, Dita. 2012. Pengaruh Struktur Modal Dan Kualitas Audit Terhadap Earning Response Coefficient. hal. 13
Zuhroh, Diana, dan I Putu Pande Heri Sukmawati. 2003, "Analisis Pengaruh Luas Pengungkapan Sosial dalam Laporan Tahunan Perusahaan terhadap Reaksi Investor", Simposium Nasional Akuntansi VI, 2003 